\title{
Use of Topographic Map Evidence to Locate a New Cenozoic Glacial History Paradigm's Deep "Hole" Rim in Northeast New Mexico and Southern Colorado, USA
}

\author{
Eric Clausen ${ }^{1}$ \\ ${ }^{1}$ Independent Investigator, Jenkintown, PA, USA \\ Correspondence: Eric Clausen, Independent Investigator, Jenkintown, PA, USA. E-mail: \\ eric2clausen@gmail.com
}

Received: February 11, 2022

Accepted: March 1, 2022

Online Published: March 3, 2022

doi: 10.5539 /jgg.v14n1p28

URL: https://doi.org/10.5539/jgg.v14n1p28

\begin{abstract}
A recently proposed Cenozoic geology and glacial history paradigm requires a thick North American continental ice sheet to have been located within an ice sheet created and occupied deep "hole" and predicts large south-oriented meltwater floods flowed across the deep "hole's" southern rim before rim uplift progressively diverted floodwaters toward the Mississippi River valley, which in time became the only deep "hole" southern exit (the accepted paradigm does not recognize such an ice sheet created deep "hole"). Possible locations for the new paradigm deep "hole" rim in Great Plains regions east of the Sangre de Cristo Mountains are considered with the one being the Purgatoire-Canadian River drainage divide in the Raton Mesas area along the Colorado-New Mexico border and a second being the Canadian-Pecos River (Arkansas River-Gulf of Mexico) drainage divide in San Miguel County (NM). Detailed topographic maps indicate streams of what could have been south-oriented melt water once crossed the two studied drainage divides with headward erosion of the northeast-oriented Purgatoire River drainage basin diverting south-oriented water toward the east-oriented Arkansas River (and Mississippi River valley) while headward erosion of east-oriented Canadian River tributary valleys beheaded south-oriented flow to the south-southeast oriented Pecos River (flowing to the Rio Grande River-which then flows to the Gulf of Mexico). While the Purgatoire-Canadian River drainage divide has some deep "hole" rim characteristics, those characteristics disappear in an eastward direction and the Canadian River, like the Purgatoire River, is an Arkansas River tributary. East-oriented Canadian River headwaters and tributary valley headward erosion diverted south-oriented flow from the Rio Grande River to the Mississippi River valley (via the Canadian and Arkansas Rivers), which means the new paradigm's deep "hole" rim southern margin should be located along or near the Arkansas River-Gulf of Mexico drainage divide.
\end{abstract}

Keywords: Arkansas River, Canadian River, Cimarron River, Pecos River, Purgatoire River, Raton Mesas

\section{Introduction}

\subsection{Statement of the Research Problem}

A recently proposed Cenozoic geologic and glacial history paradigm (new paradigm) describes large and prolonged floods flowing across the North American east-west continental divide (Clausen, 2020). The floods originated from a thick continental ice sheet located where ice sheets are usually recognized to have been and which was heavy enough to raise surrounding regions (including mountain ranges) as meltwater floods flowed across them. Uplift of surrounding regions, when combined with deep ice sheet erosion, created a large North American continent deep "hole" in which the ice sheet was located. A deep "hole" rim surrounded the ice sheet and when fully uplifted the rim forced all south-oriented meltwater to exit via the Mississippi River valley. The accepted Cenozoic geologic and glacial history paradigm (accepted paradigm) does not recognize such a continental ice sheet created deep "hole" nor does the accepted paradigm see massive and prolonged meltwater floods flowing across rising mountain and plateau regions. Using Thomas Kuhn's (1970) terminology the new and accepted paradigms are incommensurable and describe quite different Cenozoic geologic and glacial histories.

The Mississippi River drainage system (according to the new paradigm) formed as deep "hole" rim uplift gradually diverted immense and prolonged south-oriented meltwater floods to flow toward the Mississippi River 
valley. Easily identified deep "hole" rim locations east of the Mississippi River are along the Ohio River-Gulf of Mexico drainage divide and the Ohio River-Atlantic Ocean drainage divide while easily identified deep "hole" rim locations west of the Mississippi River are along the North American east-west continental divide in southern Canada, Montana, Wyoming, and northern Colorado and then along the Sangre de Cristo Mountains crestline to at least the Colorado-New Mexico border and also possibly along the Arkansas River-Gulf of Mexico drainage divide to the north of the Wichita, Arbuckle, and Ouachita Mountain areas of Oklahoma and Arkansas. Not so easily determined are deep "hole" rim locations between the Sangre de Cristo Mountains and the Wichita Mountains. Clausen, (2021) who previously had suggested the rim followed the Missouri-Arkansas River drainage divide later suggested the logical deep "hole" rim location should be along the Arkansas River-Gulf of Mexico drainage divide, but then based on further study suggested the deep "hole" rim may have followed the Sangre de Cristo Mountains crestline southward before turning in an east direction along what is now the Purgatoire-Canadian River drainage divide (which is located within the Arkansas River drainage basin-see figure 1). Another possibility is much of the east-oriented Arkansas River drainage basin follows a broad deep "hole" rim zone. The question addressed here is did the new paradigm's deep "hole" rim extend only to the Purgatoire-Canadian River drainage divide or was the deep "hole" rim a broad zone extending further south along the Sangre de Cristo Mountains crest into New Mexico and to the Canadian-Pecos River drainage divide (which is an Arkansas River-Gulf of Mexico drainage divide segment)?

\subsection{Geographical Location}

Detailed topographic map evidence was used to compare and contrast two possible southern deep "hole" rim locations (indicated by red rectangles in figure 1). Both study areas lie along the northeast-trending Jemez lineament described by Magbami et al (2004) and others. The first location is along the Colorado-New Mexico border where basaltic lava capped mesas, referred to by Lee (1921) as the Raton Mesas, are found along the Purgatoire-Canadian River drainage divide and further to the east near the Purgatoire-Dry Cimarron River drainage divide (see figure 2). Beginning at Raton Pass and proceeding east some larger mesas include Bartlett Mesa, Raton Mesa, Barela Mesa, Johnson Mesa, Mesa de Maya, Jesus Mesa and Black Mesa. These and other smaller, but similar mesas are basaltic lava capped and steep-sided upland areas now standing several hundred meters above Great Plains regions located to the north and south and are evidence of a mostly removed high-level east-sloping erosion surface. East-oriented Dry Cimarron River headwaters begin on Johnson Mesa and then flow in a canyon located south of Mesa de Maya, Jesus Mesa and Black Mesa (which extends eastward to reach the New Mexico-Oklahoma border). The Raton Mesas form a 150-kilometer-long discontinuous topographic barrier entirely contained within the large Arkansas River drainage basin and are located between the northeast-oriented Purgatoire River drainage basin (north) and south- and east-oriented Canadian River and east-oriented Cimarron River headwaters (south).

The second possible southern deep "hole" rim location is in San Miguel County, (NM) where the Canadian-Pecos River drainage divide extends from the southern Sangre de Cristo Mountains southeastward onto the Great Plains (see figure 3). The Canadian-Pecos River drainage divide separates the Arkansas River drainage basin from drainage flowing to the Gulf of Mexico (without first flowing to the Mississippi River valley). The Pecos River begins between the Santa Fe Mountains (east) and Sangre de Cristo Mountains (west) in the San Miguel County northwest corner and flows in south and southeast directions to join the Rio Grande River. The Gallinas River is a southeast- and south-oriented Pecos River tributary beginning in the Santa Fe Mountains before flowing onto the Great Plains near Las Vegas, New Mexico. Just a few kilometers north of Gallinas River headwaters is the southeast- and east-oriented Sapello River, which flows to the southeast- and east-oriented Mora River which then flows to south-oriented Canadian River headwaters. Between the Sapello (and the larger Mora) and Gallinas River drainage basins is the Arkansas River-Gulf of Mexico drainage divide. South of the Purgatoire-Canadian River drainage divide the Canadian River flows in an east-southeast and then (south of Raton) a south direction to and across the Las Vegas Plateau before entering an approximately 100 kilometer-long and 300-400-meter-deep south-oriented bedrock canyon as it crosses the Canadian Escarpment (the Las Vegas Plateau southern end). Downstream from the canyon the south-oriented Canadian River joins the south- and east-oriented Conchas River and turns in an east direction to flow in a valley influenced by evaporite-dissolution subsidence (Gustavson, 1986) between the Canadian Escarpment (north) and the Caprock Escarpment (south). 


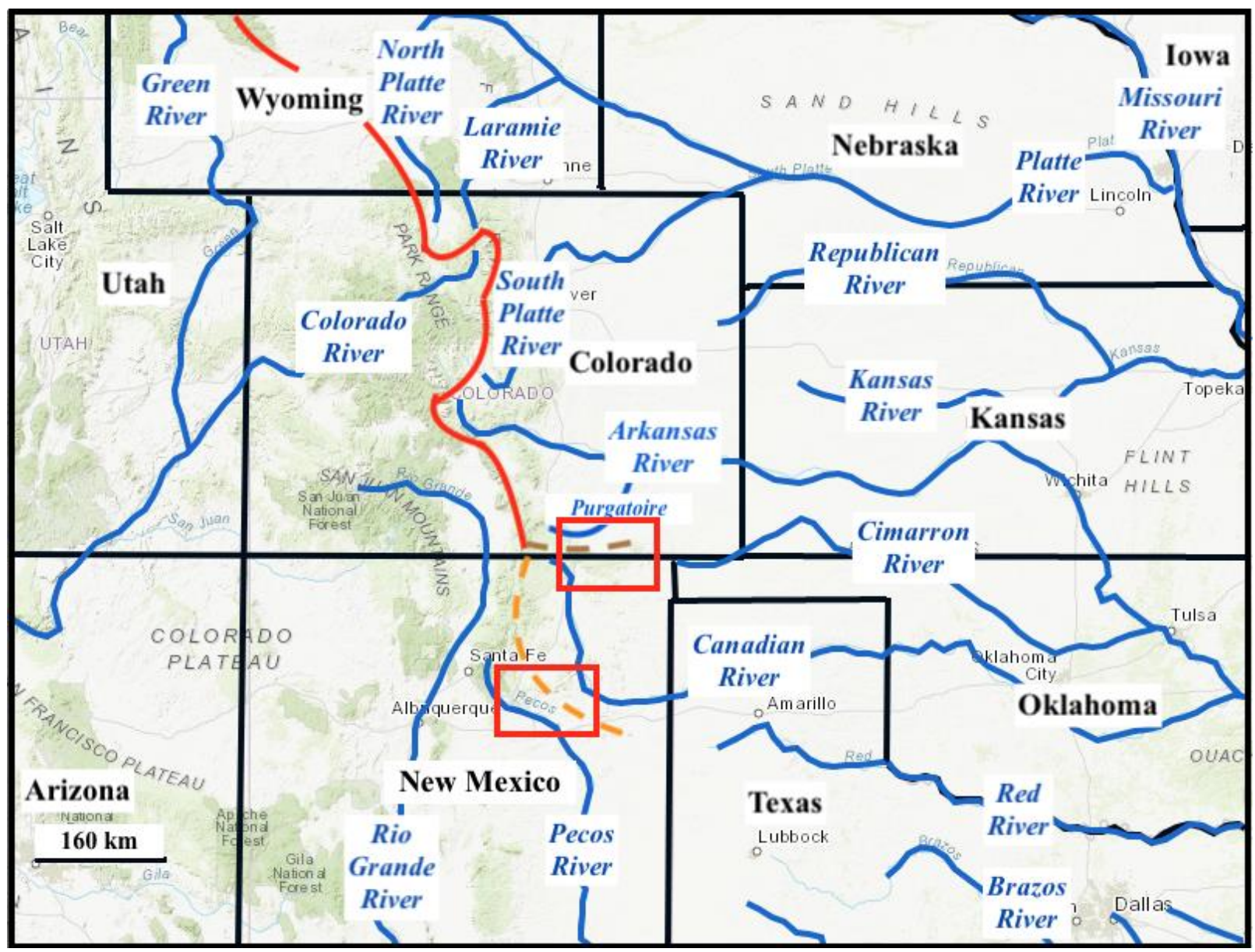

Figure 1. Modified map from United States Geological Survey (USGS) National Map website showing how this paper's study regions (red rectangles) relate to state boundaries and major rivers. Red line shows previously identified deep "hole" rim locations and dashed orange and brown lines show two possible deep "hole" rim locations tested in the study reported here.

\subsection{Previous Work}

More important to the study reported here than any published accepted paradigm interpretations is paradigm neutral United States Geological Survey (USGS) work which resulted in the publication of detailed topographic maps covering the entire contiguous 48 states (these maps are not cited in this paper's reference section but are now available at the USGS National Map website). USGS detailed topographic maps show many of the landform features needed to reconstruct former drainage routes and have an advantage over satellite and air photos in that most drainage routes and some landform features are named. Working with named drainage systems and landform features greatly simplifies drainage history interpretations. Unfortunately, drainage histories determined from the paradigm neutral topographic maps rarely correspond with commonly accepted paradigm Cenozoic geologic and glacial history interpretations and for this reason previous investigators have ignored most USGS topographic map drainage system and erosional landform evidence. The new paradigm was developed using Missouri River drainage basin detailed topographic map drainage system and erosional landform evidence and leads to a completely different and incommensurable Cenozoic geologic and glacial history than what the accepted paradigm has permitted previous researchers to describe.

With the exception of Clausen's work all previous regional geomorphological research has been done from an accepted paradigm perspective. Pearl (1971, p. 25) for example commented "in late Miocene or early Pliocene time, the Rocky Mountains in Colorado were uplifted [and]...the material eroded from the mountains was carried eastward and deposited by streams... as the Ogallala Formation." Much of the early and mid- $20^{\text {th }}$ century work is summarized in Fenneman (1931) and Thornbury (1965) who describe Ogallala Formation deposits on the High Plains to the east of the Rocky Mountains and consider the Raton Mesas to be a belt of basaltic lava 
covered mesas extending eastward in the New Mexico-Colorado border area from near Raton, New Mexico to about the Oklahoma western border. Thornbury (p. 315) describes deep regional erosion following the period of extensive Raton Mesa area volcanism, but does not otherwise explain the origin of gaps eroded between the basalt covered mesas. Further to the south and based on Plummer (1932) and King (1948) Thornbury (p. 317) says "The original drainage of what is now the upper Pecos Valley was to the east across the High Plains. The Pecos River apparently began as a short tributary of the Rio Grande... [and] cut its way headward and one by one pirated the eastward-flowing streams." Without addressing the Canadian-Pecos River drainage divide Thornbury goes on to say "the date of the piracies can be placed rather definitely as post-Pliocene, thus making it likely they took place early in Pleistocene time."

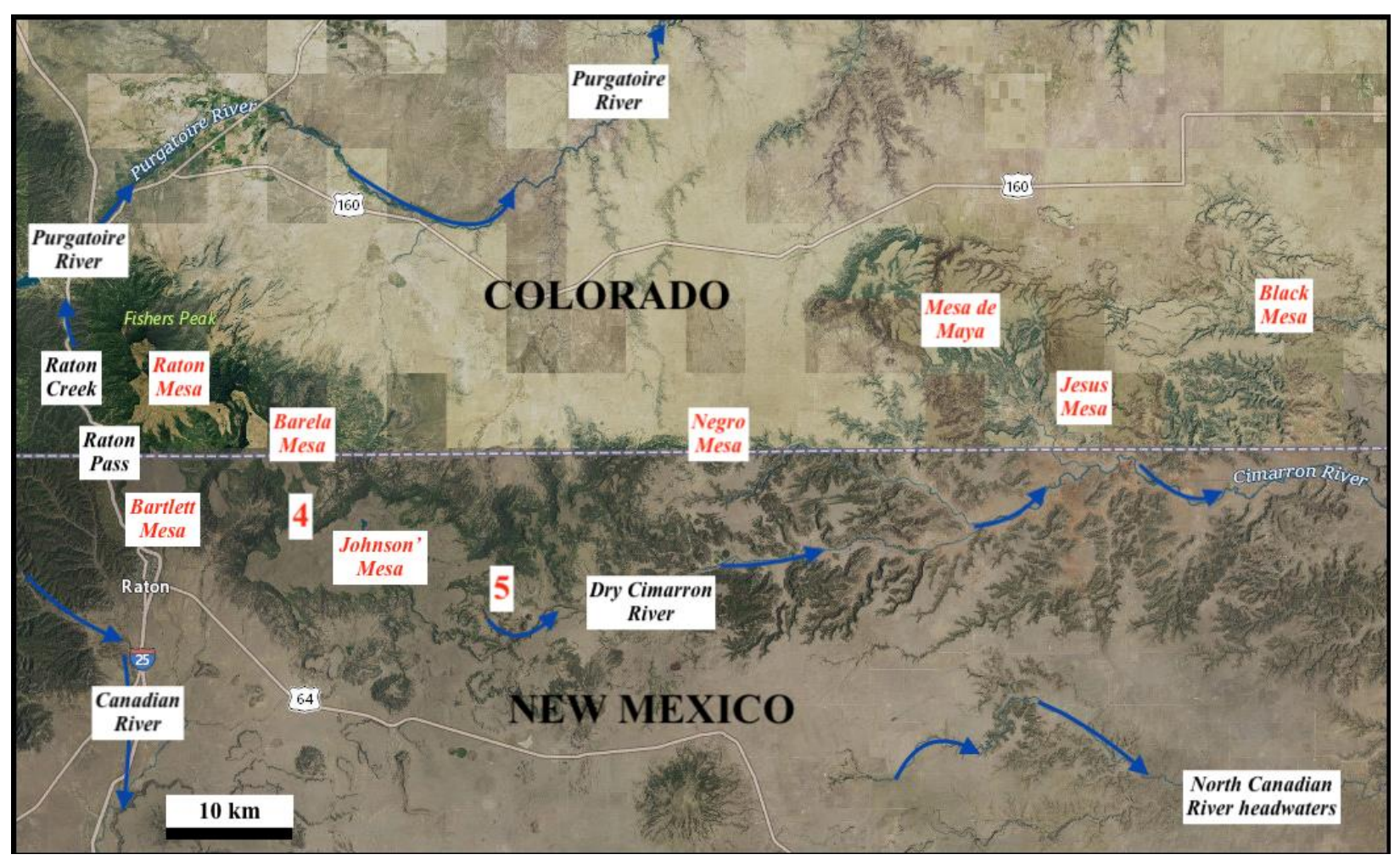

Figure 2. Modified imagery from USGS National Map website showing the Raton Mesas region along the Colorado-New Mexico border. Blue arrows emphasize major drainage routes. Red numbers show approximate locations for this paper's figures 4 and 5 .

Spiegel (1972) noted early Cenozoic uplift created the ancestral Sangre de Cristo Mountains, which during Miocene and Pliocene time resulted in Ogallala Formation deposition in an eastward direction across northeastern New Mexico and suggested the courses of the Canadian River and its tributaries may be "related to the extensive early to middle Pleistocene system of normal faults." Dolliver (1984, p. 5) reports the basal Ogallala Formation within the Canadian River drainage basin originated in the southern Sangre de Cristo Mountains when following "late Miocene-early Pliocene uplift of a climatically modified Eocene erosion surface... entrenched montane border streams carried Ogallala sediment eastward and southeastward [from the southern Sangre de Cristo Mountains] across northeastern New Mexico." He also reports "eastward-flowing Raton-High Plains Canadian tributaries established their modern courses during a short interval spanning the Pliocene-Pleistocene boundary... Entrenchment was most pronounced just north of the Canadian-Arkansas divide, where the early Pleistocene Cimarron River became incised... The north-south reach of the upper Canadian River probably evolved by early Pleistocene time through headward migration and beheading of east-flowing montane drainage." Dolliver (1985, p. 315) explains the period of extensive regional erosion by stating "Geomorphic stability of the Ogallala alluvial plain ended and incision of the Canadian breaks began with abrupt and apparently successive episodes of Plio-Pleistocene tectonism and climatic change" and continues (p. 316) "Excavation of the Canadian breaks...began with the superposition of two late Pliocene drainage 
systems onto the terminal Ogallala alluvial plain" with one system north and the other south of the present Canadian River.

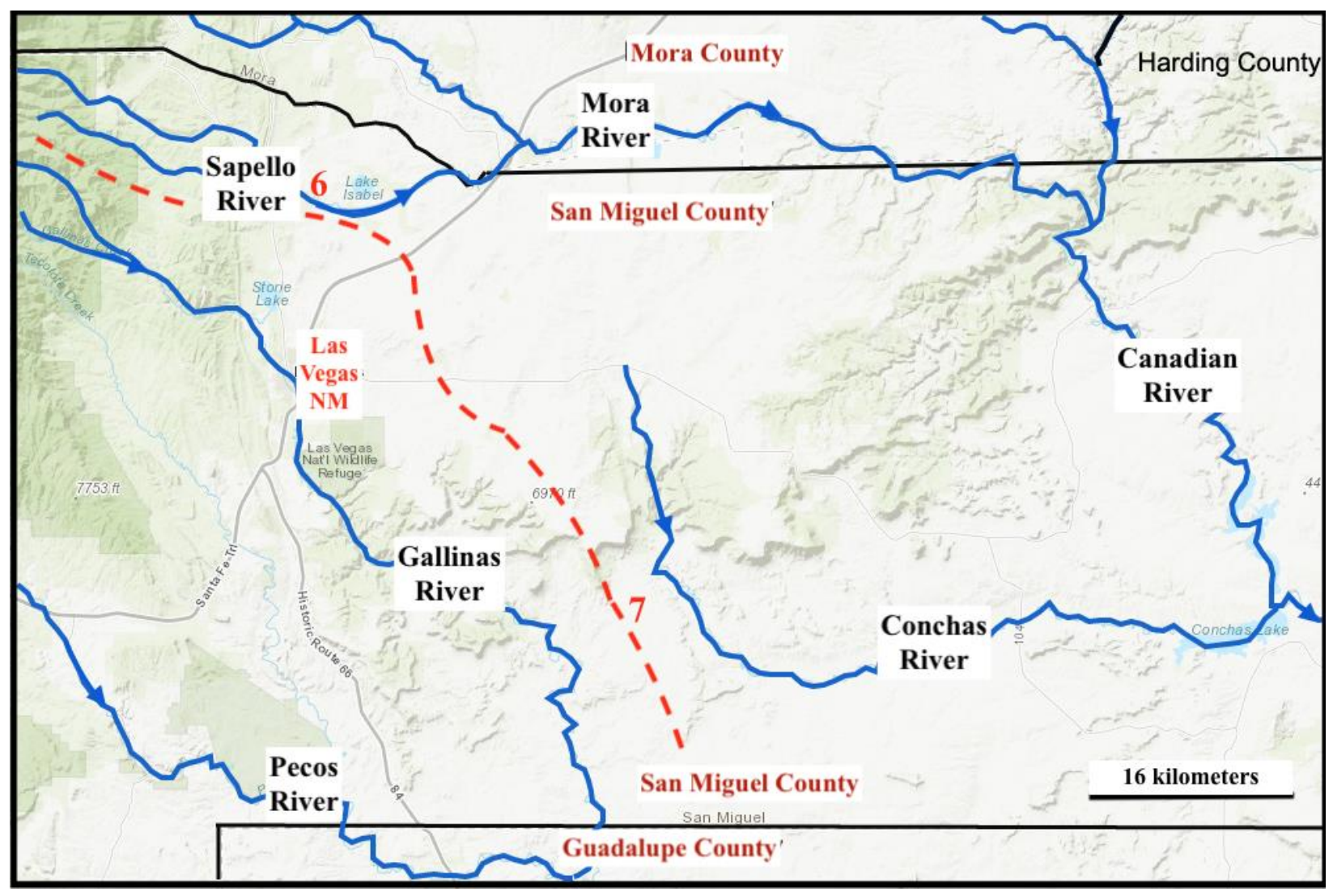

Figure 3. Modified map from USGS National Map website showing the San Miguel County, New Mexico Canadian-Pecos River drainage divide (dashed red line) and major drainage routes. Red numbers show approximate locations for this paper's figure 6 and 7.

Pazzaglia and Kelley (1998. p. 229) observe "the Jemez lineament... is thought to be a significant Proterozoic structural feature that has influenced Quaternary volcanism along its trend." They also comment (p. 233) "No thick accumulations of the Ogallala Formation occur in eastern New Mexico or southeastern Colorado (the region immediately adjacent to the Rio Grande rift uplift), an observation consistent with the lack of a crustal downwarp to preserve the detritus shed from the Southern Rockies during the late Tertiary." Four years later Wisniewski and Pazzaglia (2002, p. 437) attribute the Canadian River's deep bedrock canyon to the "complex interaction of post-Laramide epeirogenic rock-uplift processes along the Jemez lineament and downstream baselevel fall caused by late Tertiary and Quaternary evaporite dissolution" with the Jemez lineament being "a lithospheric-scale structure with prolific late Cenozoic volcanism along its trend." Based on Canadian River incision rates, calculated from ${ }^{40} \mathrm{Ar} /{ }^{39} \mathrm{Ar}$ dated basalts within the canyon and on Canadian Escarpment elevations (north of the Canadian River valley) and Caprock Escarpment elevations (south of the valley) they "suggest that post-Laramide, thermally driven epeirogeny is in part responsible for the high-standing topography evident on the western Great Plains of northeastern New Mexico.

Nereson et al (2013, p. 538, fig. 14) show Late Miocene (6 Ma), Early Pliocene (4.4 Ma), Middle Pliocene (3.6 $\mathrm{Ma})$ and Pleistocene (2.2 Ma) reconstructions of northeast New Mexico drainage systems. Their Late Miocene reconstruction shows four rivers originating in the Sangre de Cristo Mountains as follows: an east-oriented ancestral Dry Cimarron River located to the north of the Raton Mesas in Colorado, an east-oriented ancestral Vermejo River located in New Mexico to the south of the Raton Mesas (and maybe turning southward in west Texas), a southeast-oriented Mora River flowing across San Miguel County, and a southeast-oriented Pecos River. The Early Pliocene map indicates a northeast-oriented Purgatoire River north of the Raton Mesas with the east-oriented Dry Cimarron River south of the Raton Mesas, the ancestral Vermejo River flowing in a southeast direction toward a West Texas evaporite collapse area, the southeast-oriented Mora River flowing toward what is 
today the east-oriented Canadian River (downstream from the canyon), and the Pecos River flowing in a south and southeast direction. The Middle Pliocene reconstruction shows the ancestral Canadian River has eroded headward across the Canadian Escarpment to capture the ancestral Vermejo River headwaters with most other rivers similar to in the Early Pliocene. Finally, the Pleistocene map shows the Canadian River has captured east-oriented Dry Cimarron River headwaters (which since early Pliocene time were located south of the Raton Mesas) and other drainage routes are similar to today.

\section{Research Method}

The new paradigm predicts to the west of the Mississippi River valley and to the east of the east-west continental divide multiple streams of south-oriented water should have first flowed across the deep "hole" rim and then as deep "hole" rim uplift progressed should have been diverted in east, northeast, and/or north directions so as to flow to major east-oriented Mississippi River tributary valleys. This prediction also means that to the south of the deep "hole" rim drainage should now flow in south and/or southeast directions to reach a major east-, southeast-, or south- oriented drainage route leading directly to the Gulf of Mexico Coastal Plain. The new paradigm also predicts that deep "hole" rim uplift diversions of south-oriented water to east-oriented Mississippi River tributary valleys should have occurred in a progressive sequence from southeast to northwest. Detailed topographic maps available at the USGS National Map website provide an excellent resource for testing these new paradigm predictions by showing present-day drainage routes, their orientations, their valley characteristics, and abandoned valleys (referred to as divide crossings) now crossing drainage divides between present-day valleys.

The study reported here began by using detailed USGS topographic maps to identify the Purgatoire-Canadian River (and Purgatoire-Dry Cimarron River) drainage divide in the Raton Mesas region and the Canadian-Pecos River drainage divide in the San Miguel County, New Mexico region. Each of the identified drainage divides was next studied to identify and describe low points (or divide crossings) where new paradigm predicted south-oriented melt water might have flowed across what is now a major drainage divide. The divide crossings were then linked to drainage routes both to the north and south of each drainage divide segment. Secondary drainage routes to the north of each studied drainage divide were then observed to determine if they were oriented primarily in north or northeast directions so as to flow to a major east-oriented Mississippi River tributary. Secondary drainage routes to the south of each of the studied drainage divides were checked to determine if they were primarily oriented in south or southeast directions to reach a major east-, southeast-, or south-oriented drainage route flowing directly to the Gulf of Mexico (without making first flowing to the Mississippi River valley). Red River (of the South) water does reach the Mississippi River delta area, but was considered for purposes of this study to flow directly to the Gulf of Mexico.

In addition, elevations of regions both north and south of each studied drainage divide were compared to determine if the presence of a "hole" to the north of one or both of the drainage divides could be detected. While primarily to the east of the San Miguel County study region, the north-facing Caprock Escarpment south of the east-oriented Canadian River valley was studied to determine if the Caprock Escarpment could be considered to be a possible southern deep "hole" rim location. Stream capture evidence seen on topographic maps was used to determine the sequence in which east-oriented valleys eroded and to determine whether headward erosion of east-oriented valleys had captured south-oriented flow as the new paradigm predicts or whether headward erosion of south-oriented valleys had captured east-oriented drainage as the accepted paradigm usually requires.

\section{Results}

\subsection{Raton Mesas Study Region}

Clausen (2021) suggested the deep "hole" southern rim may have followed the Purgatoire-Canadian River drainage divide between the Sangre de Cristo Mountains and Raton Pass, but did not address Purgatoire-Canadian River and Purgatoire-Dry Cimarron River drainage divide areas to the east of Raton Pass. Raton Pass has an elevation of 2375 meters and serves as an important north-south transportation corridor. Figure 2 shows the west-to-east oriented Raton Mesas study region, major drainage routes, and provides names for a few of the many basalt-covered mesas. Bartlett Mesa which is immediately to the east of Raton Pass has a high point of 2623 meters and stands about 500 meters above the nearby town of Raton to the south. North of Bartlett Mesa, but separated by a narrow valley, is the 100-200-meter-higher Raton Mesa (also known as Fishers Peak Mesa) the upper surface of which stands almost 1000 meters above the Great Plains areas located to the north. Between the two mesas is a divide crossing in a northwest-to-southeast oriented valley (referred to here as Segerstrom Pass and which has a floor elevation of 2533 meters) which links northwest-oriented McBride Creek in the Purgatoire River drainage basin with southeast-oriented Segerstrom Creek in the Canadian River drainage 
basin. Before regional erosion lowered the Purgatoire River drainage basin (to the north) what was probably a large stream of south-oriented water flowing along the alignment of today's north-oriented Raton Creek (a Purgatoire River tributary) diverged into two channels so as to flow around an emerging Bartlett Mesa upland with one channel leading in a southeast direction to Segerstrom Creek and south-oriented Chicorica Creek while the other channel continued in a south direction to erode Raton Pass. The Raton Pass channel was the more direct route and was able to erode a deeper valley which then beheaded the southeast-oriented channel to Segerstrom Creek which reversed flow to the northwest of Segerstrom Pass so as to create northwest-oriented McBride Creek.

Southeast of Raton Mesa, but separated from it, is Barela Mesa which has a southern extension known as Horse Mesa. South-oriented Chicorica Creek flows in a 300-meter-deep canyon between Bartlett Mesa and Horse Mesa to eventually reach the Canadian River. Southeast-oriented Segerstrom Creek now originates on Raton Mesa and flows from the Segerstrom Pass area in the previously described valley between Raton Mesa (north) and Bartlett Mesa (south) to join south-oriented Chicorica Creek. San Francisco Pass (floor elevation about 2565 meters) is a 100-meter-deep or deeper northwest-southeast oriented divide crossing at the head of the south-oriented Chicorica Creek valley between Little Fishers Peak Mesa (a Raton Mesa eastern extension) and Burro Mesa (a Barela Mesa north-northwestern extension). North of San Francisco Pass and Burro Mesa are north- and northeast-oriented San Francisco Creek headwaters which flow down steep slopes to reach Great Plains areas (now with elevations almost 800 meters lower than the Burro Mesa high points) to eventually reach the Purgatoire River. Shallow valleys crossing Burro Mesa suggest the south-oriented Chicorica Creek valley was initiated by south-oriented water which flowed across the Burro Mesa surface from what is now the deep San Francisco Creek drainage basin with the final flow moving in a southeast direction through San Francisco Pass. South-oriented water probably continued to reach the Chicorica Creek valley via Segerstrom Pass which is about 32 meters lower than San Francisco Pass until the deeper Raton Pass channel (floor elevation 2375 meters) captured all of the south-oriented flow. Subsequent headward erosion of the much deeper Purgatoire River drainage basin ended all south-oriented flow into the Chicorica Creek drainage basin and removed hundreds of meters of sediment from the region to the northeast of Raton and Burro Mesas.

South and east of Barela and Horse Mesas is Johnson Mesa with Manco Burro Pass (number 1 in figure 4 with a floor elevation of 2408 meters) located in the valley separating Barela and Johnson Mesas where higher elevations exceed 2500 meters. Manco Burro Pass has a northeast-southwest orientation and links northwest- and southwest-oriented East Fork Chicorica Creek (in the Canadian River drainage basin) with northeast- and north-oriented San Isidro Creek (in the Purgatoire River drainage basin). Valley floor elevations on either side of Manco Burro Pass rapidly decrease to below 2250 meters with the San Isidro Creek valley floor elevation being less than 2000 meters at the figure 4 northeast corner while the Chicorica Creek valley floor crosses the 2000-meter contour a short distance south of figure 4. Important to understanding the figure 4 drainage history are southeast-oriented Rathburn and Bear Canyons which drain as barbed tributaries into the northeast- and north-oriented San Isidro Creek headwaters. These prominent barbed tributaries suggest south- and southwest-oriented water which flowed along the now northeast- and north-oriented San Isidro Creek alignment eroded Manco Burro Pass but was reversed by regional uplift and/or by the progressive headward erosion of the deep northeast-oriented Purgatoire River drainage basin (which is located to the north of Johnson Mesa) while southeast-oriented water continued to flow across Barela Mesa to erode the southeast-oriented Rathburn and Bear Canyon valleys. Mesa surface and pass floor elevations decrease in an eastward direction suggesting regional uplift must have been occurring in the west and/or that greater erosion was occurring in the east (or probably some combination of the two).

Continuing in an east direction to the Johnson Mesa eastern end figure 5 illustrates Trinchera Pass (another well-defined divide crossing with a floor elevation of about 2170 meters) which links the north-oriented Trinchera Creek drainage basin (in the Purgatoire River drainage basin) with the east-oriented Cimarron River drainage basin (which originates as the Dry Cimarron River on Johnson Mesa). A triple drainage divide exists at Dale Mountain between south-oriented drainage to the Canadian River, southeast- and east-oriented drainage to the Dry Cimarron River, and north-oriented drainage to the Purgatoire River. The Johnson Mesa surface elevation decreases from more than 2500 meters south of Manco Burro Pass to slightly more than 2300 meters in the figure 5 center. The Chavez Mesa surface elevations to the east of Trinchera Pass are slightly lower and are generally in the 2250-to-2300-meter range. Trinchera Pass appears to have been eroded by south-oriented water which initially flowed into what is now the Canadian River drainage basin, but which was captured by headward erosion of the east-oriented Dry Cimarron River valley (note how Trinchera Creek begins on Johnson Mesa as a southeast-oriented stream-such a fishhook drainage pattern is an indication that the flow direction has been 
reversed). To the south and east of figure 5 a well-defined divide crossing just east of Sierra Grande links north-northeast oriented Pinabete Creek headwaters (flowing to the Dry Cimarron River) with southeast-oriented Gallegos Creek headwaters (flowing to the Canadian River) and indicates that prior to Dry Cimarron River valley headward erosion south-oriented water once flowed across the figure 5 map area to the Canadian River.

Shallow valleys between Chavez, Davis, and Brown Mesas (to the east of figure 5) were probably carved by south-oriented streams of water flowing from what is now the Purgatoire River drainage basin across the present-day east-oriented Dry Cimarron River valley to what is now a gradual south-oriented slope eventually leading to the east-oriented Canadian River. This south-oriented flow probably had also moved across the Davis Mesa surface (to the northeast of figure 5). Emery Gap (floor elevation about 1945 meters) is a 300-meter-deep valley between the Brown Mesa upland surface and the Negro Mesa upland surface and is used today as an important transportation route. A 17-kilometer wide and 300-meter-deep gap exists between the Negro Mesa eastern end and the Mesa de Maya upland surface western end. Within this wide gap Purgatoire-Dry Cimarron River drainage divide elevations are lower than 1900 meters and reach a low point of about 1800 meters between north-oriented Chacuaco Creek and south-southeast oriented Cow Canyon. To the east of the wide gap the Mesa de Maya, Jesus Mesa, and Black Mesa group form an almost continuous upland barrier to the north of the east-oriented Dry Cimarron River valley, although with progressively lower upland surface elevations which decrease from more than 2100 meters at the Mesa de Maya western end to less than 1500 meters at the Black Mesa eastern end. To the north of the Mesa de Maya eastern half and of Black Mesa and draining the Mesa de Maya and Black Mesa northern flanks as well as several smaller mesas and some Great Plains regions to the north is the southeast-oriented Carrizo Creek drainage basin which eventually empties to the Dry Cimarron River.

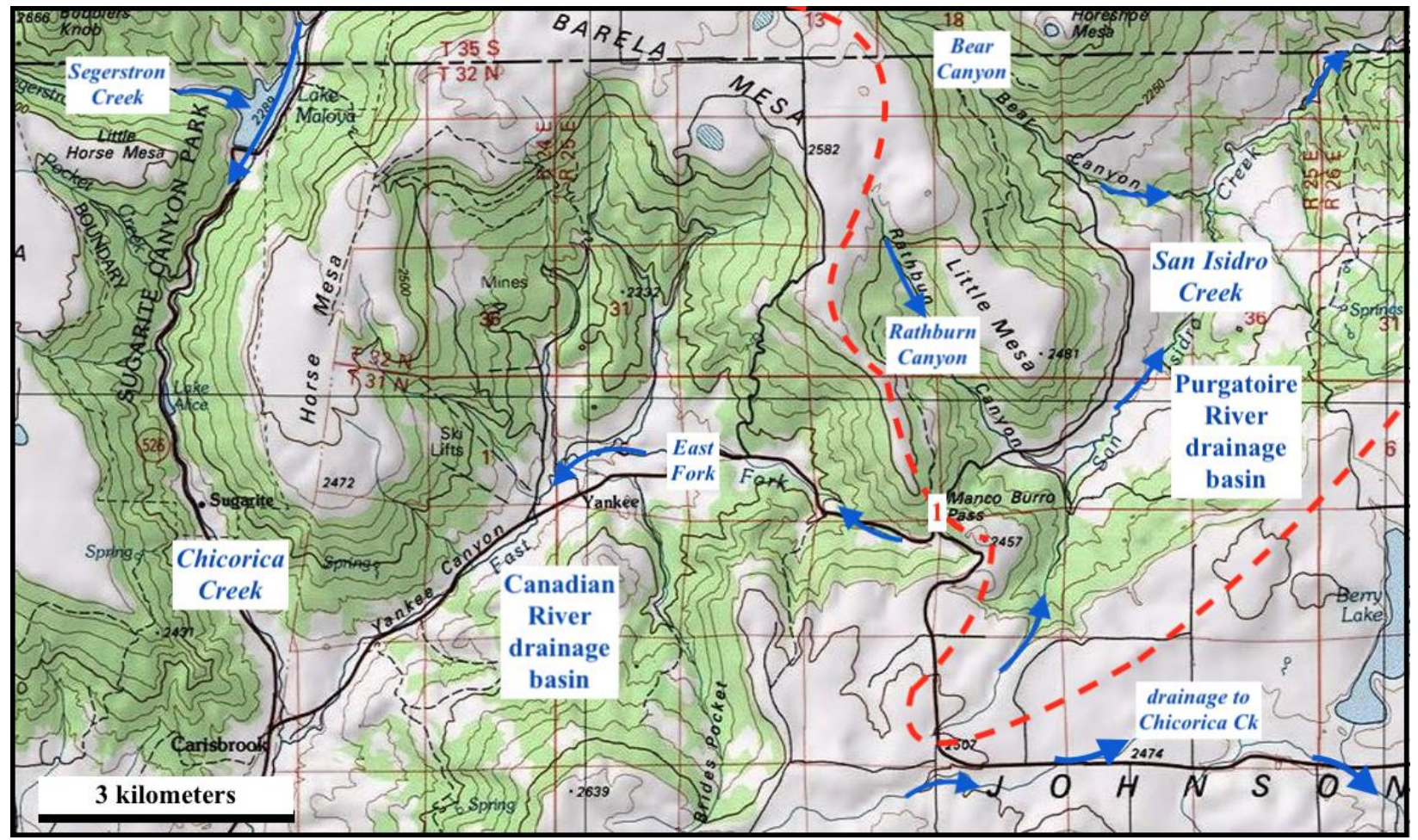

Figure 4. Modified topographic map from USGS National Map website showing Manco Burro Pass location (red number 1) between Barela and Johnson Mesas. Red dashed line shows approximate Purgatoire-Canadian River drainage divide location. Contour interval is 50 meters.

High elevation basalt covered mesas extending from Raton Mesa to Johnson Mesa help form the Purgatoire-Canadian River drainage divide while more eastern mesas for a distance are located to the south of the Purgatoire-Dry Cimarron River drainage divide. Evidence in the form of gaps between the mesas and of shallow valleys now found crossing some upland mesa surfaces suggests multiple streams of south-oriented water once flowed across the Purgatoire-Canadian River and the Purgatoire-Dry Cimarron River drainage 
divides. West of the Negro Mesa eastern end the south-oriented water appears to have been diverted by Raton Mesas region uplift to flow in east, north, or northeast directions. The Purgatoire River drainage basin to the north of the west-to-east oriented Raton Mesas chain has significantly lower elevations than the south-sloping Canadian River drainage basin elevations immediately to the south (and further to the east to the south of the east-oriented Dry Cimarron River drainage basin). Topographic maps showing the larger Purgatoire River drainage system suggest northeast-oriented Purgatoire River valley segments eroded headward across multiple southeast-oriented streams of water indicating something diverted southeast-oriented water in a northeast direction, although such interpretations require the removal of many hundreds of meters of sedimentary rocks from many Purgatoire River drainage basin areas. While the Purgatoire-Canadian River drainage divide has many deep "hole" rim characteristics those characteristics become less obvious further to the east-especially along the Purgatoire-Dry Cimarron River drainage divide. A convincing case for the deep "hole's" southern rim cannot be made in the region to the east of Negro Mesa.

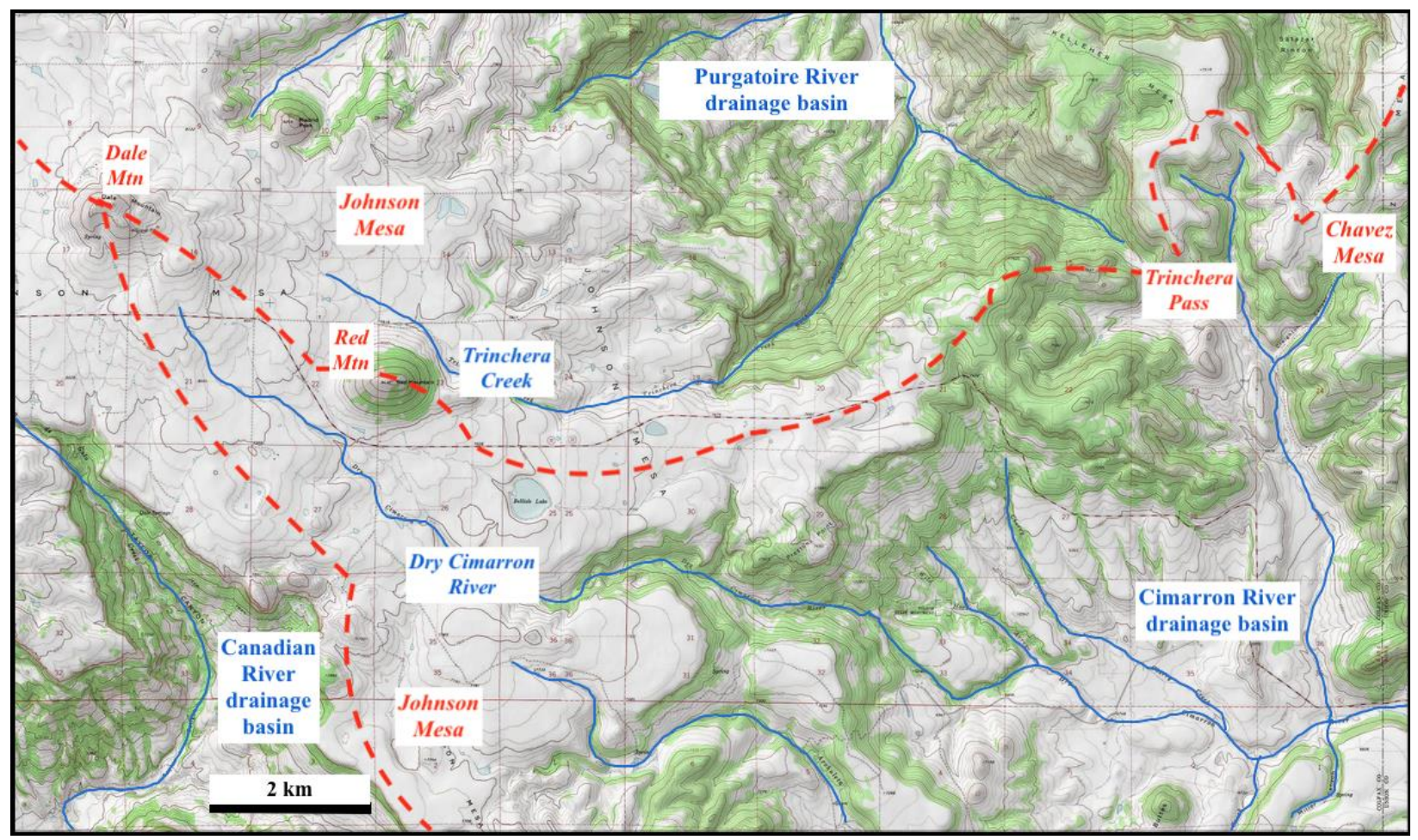

Figure 5. Modified topographic map from the USGS National Map website showing the Johnson Mesa eastern end, Trinchera Pass, and the Chavez Mesa western half with dashed red lines showing major drainage divides.

Contour interval is 20 feet (6 meters).

\subsection{San Miguel County, New Mexico Study Area}

The San Miguel County, New Mexico study region is where the Canadian (Arkansas)-Rio Grande River drainage divide turns from the Sangre de Cristo Mountains and extends in what might be considered a southeast and south-southeast direction onto the Great Plains. In figure 3 the south-oriented Canadian River is joined by the south- and east-oriented Conchas River at a point approximately 170 kilometers (as the crow flies) south of Raton Pass and turns to flow in an east direction to eventually join the Arkansas River. Canadian River headwaters originate in the mountains and flow in roughly an east-southeast direction near the Purgatoire-Canadian River drainage divide almost to Raton Pass before turning in a south direction to flow across upland plains areas 100- to 200-meters higher than Purgatoire River valley elevations to the north of Raton Pass and then to enter the (approximately) 100-kilometer long and up to 400-meter deep south-oriented Canadian River Canyon which was eroded headward from the south-facing Canadian Escarpment. The Conchas River originates as a south-oriented river on the Las Vegas Plateau to the west of the Canadian River Canyon before entering a south-oriented canyon (about 10 kilometers long) to cross the Canadian Escarpment and then turns in an east direction to join the Canadian River. South of the Conchas River Canyon a low drainage divide 
separates the east-oriented Conchas River downstream valley from the south-southeast oriented Pecos River drainage basin. Further to the east and south of where the Conchas and Canadian Rivers meet is the western end of the north-facing 200- to 300-meter high Caprock Escarpment which becomes the Canadian (Arkansas)-Pecos (Rio Grande) River drainage divide. Isolated mesas south of the south-facing Canadian Escarpment and further to the east between the Canadian Escarpment and north-facing Caprock Escarpment are remnants of what was once a continuous upland surface before east-oriented Conchas-Canadian River valley headward erosion.

The San Miguel County (NM) Canadian-Pecos River drainage divide western end begins in the Santa Fe Mountains as a divide between the Sapello and Gallinas River drainage basins. High unnamed divide crossings (low points along what are now mountain ridges) indicate multiple streams of probably south-oriented water once flowed across divides separating what are now east- and southeast-oriented headwaters of both rivers. Continuing eastward to the mountain front well-defined north-south oriented through valleys seen in figure 6 which are separated by hogback ridges link east-southeast- and northeast-oriented Sanguijuela Arroyo (draining to the Sapello River) with the nearby east-southeast and south-southeast oriented Canon Bonita (draining to the Gallinas River). On the Las Vegas Plateau a Sapello-Gallinas River drainage divide segment for a short distance is along the east-oriented Sapello River south valley wall and a north-to-south oriented abandoned valley can be traced headward (in a north direction) from that location across the drainage divide between the Sapello River and southeast-oriented Arroyo Jara (a Sapello River tributary), then across the Mora River valley, and finally headward along the valley of a south-oriented Mora River tributary (Coyote Creek) to reach a chain of north-to-south oriented valleys along the Sangre de Cristo Mountains front. While flow routes north of the Mora River drainage basin are not addressed here, water almost certainly once flowed in a south direction across what are now the Mora River, Arroyo Jara, and Sapello River valleys to reach the south-southeast oriented Gallinas River in the Rio Grande River drainage basin.

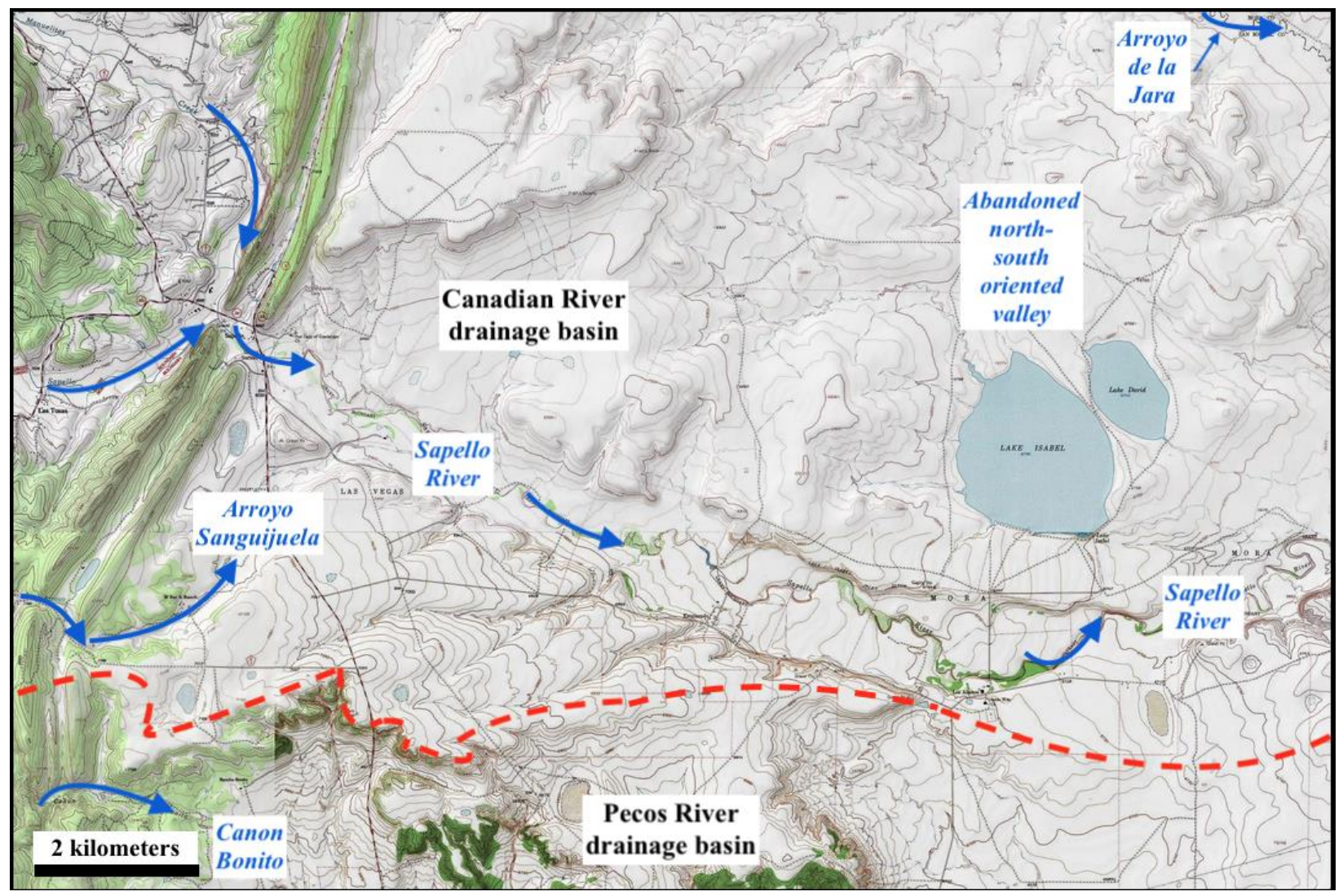

Figure 6. Modified topographic map from the USGS National Map website showing the Canadian-Pecos River drainage divide (red dashed line) north of Las Vegas, New Mexico. Canon Bonito drains to the Gallinas River. The contour interval is 20 feet ( 6 meters).

In addition to the above-described drainage divide between the Sapello and Gallinas River drainage basins the Canadian (Arkansas)-Pecos (Rio Grande) River drainage divide continues in a south-southeast direction between 
the Conchas and Gallinas River drainage basins (see figure 3). To the south of the Canadian Escarpment detailed topographic maps show identifiable through (abandoned) valleys which must have been eroded by south-oriented water flowing from the south- and east-oriented Conchas River drainage basin to the south-southeast oriented Gallinas River (and also directly to the south-southeast oriented Pecos River downstream from where the Gallinas River joins it). Figure 7 illustrates a detailed topographic map showing a region to the south of the Conchas River Canyon where one such through valley links a northeast-oriented Conchas River tributary valley with the south-southwest oriented Alamito Creek valley (which joins the Gallinas River a short distance to the north of where the Gallinas River joins the Pecos River). South-oriented water flowing in the through valley seen in figure 7 moved along the Mesa Montoya southeast corner and a somewhat similar through valley at the Mesa Montoya northwest corner links a northeast-oriented Conchas River tributary valley with the south-oriented Indio Arroyo valley draining to the Gallinas River. The relatively smooth Mesa Montoya upper surface (located almost directly to the south of the Conchas River Canyon) is almost 300 meters lower than Las Vegas Plateau elevations to the north of the south-facing Canadian Escarpment and slopes gradually in south and southeast directions (and is drained in a south direction to the Gallinas River). The smooth Mesa Montoya upper surface was probably beveled by massive amounts of water flowing from the Conchas River Canyon to what is today the Pecos (Rio Grande) River drainage basin. Shallow through valleys crossing the Mora-Conchas River drainage divide to north of the Conchas River headwaters indicate the south-oriented water must have come from north of the present-day Conchas River drainage basin and was beheaded by headward erosion of the east-oriented Mora River valley.

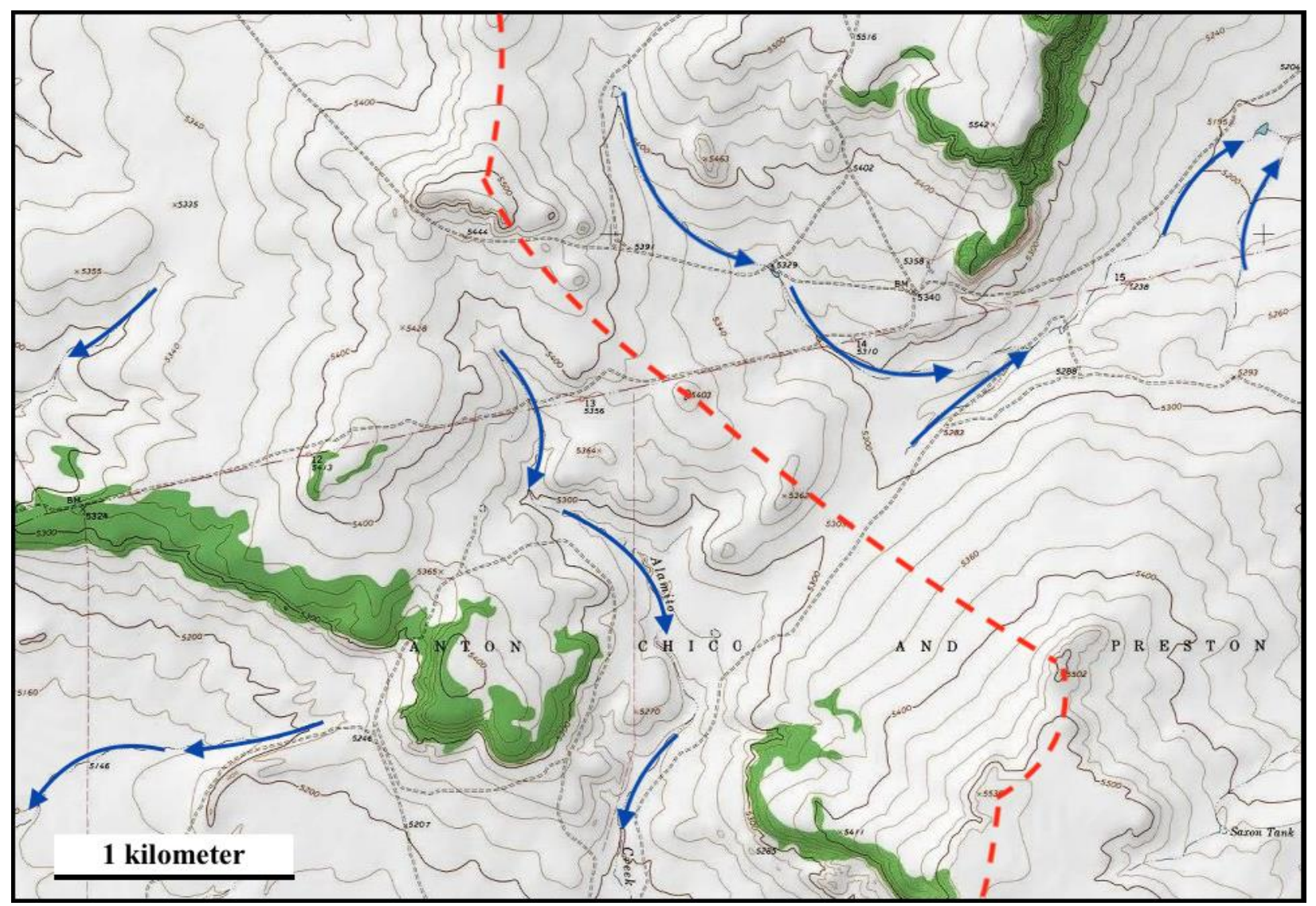

Figure 7. Modified topographic map from the USGS National Map website showing a through valley crossing the Conchas-Gallinas River drainage divide (shown with dashed red line). The contour interval is 20 feet (6 meters). Conchas Canyon is to the north of the figure.

Contrary to published interpretations which claim headward erosion of the south-southeast oriented Pecos River valley beheaded east-oriented streams the San Miguel County topographic map evidence shows headward erosion of east-oriented valleys captured multiple streams of south-oriented water which had been flowing to the south-southeast oriented Pecos River. As discussed here and illustrated in figure 7 headward erosion of the 
east-oriented Conchas River valley captured south-oriented water which had been flowing to what are now the Gallinas and Pecos River valleys and later (further to the north) headward erosion of the east-oriented Mora River valley beheaded south-oriented flow moving toward the south-oriented Conchas River Canyon. While some figure 6 evidence could be interpreted to suggest headward erosion of a south-oriented valley is about to capture the Sapello River the labelled north-to-south oriented abandoned valley strongly suggests headward erosion of the east-oriented Sapello River valley captured south-oriented flow which was later captured by headward erosion of the southeast-oriented Arroyo Jara valley and next by headward erosion of the southeastand east-oriented Mora River valley. In other words, prior to headward erosion of the east-oriented Canadian River drainage system multiple streams of south-oriented water flowed across the region to reach the Rio Grande River drainage basin. Headward erosion of the east-oriented Canadian-Conchas River valley (which eroded headward from the Arkansas River and Mississippi River valleys) created the Canadian (Arkansas)-Pecos (Rio Grande) River drainage divide.

\section{Discussion}

Determining whether the new paradigm's deep "hole" rim between the Rocky Mountains and the south-oriented Mississippi River valley followed a topographically high drainage divide, such as the Ohio River-Atlantic Ocean drainage divide or consisted of a wider zone such as the east-oriented Arkansas River drainage basin requires a decision as to whether present-day topographic features or drainage basins should be used when identifying the deep "hole" rim location. If topography is used as the defining criteria the Purgatoire-Canadian River drainage divide today forms a significant topographic barrier as it extends eastward from the Sangre de Cristo Mountains. However, further to the east that topographic barrier disappears and the Cimarron River is just one of several roughly parallel and relatively closely spaced east-oriented Arkansas River tributaries with the Canadian River being the southernmost of those major east-oriented Arkansas River tributaries. In other words, the prominent topographic barrier does not continue from the Raton Mesas area in an eastward direction which means the deep "hole" rim is either located further to the south or that the east-oriented Arkansas River drainage basin (and perhaps other adjacent east-oriented drainage basins both north and south of the Arkansas River drainage basin) may now be located along a broad deep "hole" rim. Clausen (2019) describes another similar (although smaller) broad deep "hole" rim in Wyoming's Great Divide Basin where today the east-west continental divide surrounds a large internal drainage region.

The San Miguel County (NM) Canadian-Pecos River drainage divide is not a topographic barrier like the east-west continental divide, the Sangre de Cristo Mountains, or even the Raton Mesas topographic high, but still separates drainage flowing to the Arkansas and Mississippi Rivers from drainage flowing more directly to the Gulf of Mexico. While not fully studied and needing further documentation a preliminary scan of topographic map evidence to the east of the San Miguel County (NM) area suggests the Arkansas River-Gulf of Mexico drainage divide does have a much stronger topographic identity than any drainage divides continuing in an eastward direction from the west-to-east oriented Raton Mesas area. For example, in eastern New Mexico (to the east of San Miguel County) and across the Texas Panhandle the Arkansas River-Gulf of Mexico drainage divide stands out topographically as the north-facing Caprock Escarpment (which forms the Canadian River drainage basin's southern wall). To the north of the Caprock Escarpment drainage is to the east-oriented Canadian River which eventually reaches the Arkansas River which in turn flows to the Mississippi River. To the south of the Caprock Escarpment at its western end is drainage to the Pecos River and to the east of that Pecos River drainage and extending eastward from eastern New Mexico is east-oriented Red River drainage, which for purposes of this report is considered to flow directly to the Gulf of Mexico.

A preliminary scan of Oklahoma topographic map evidence suggests the deep "hole" rim southern margin should probably continue along the Wichita and Arbuckle Mountains crestlines although the Washita River drainage basin is located between the Canadian-Red River drainage divide and those mountains. The Washita River is interesting as it begins as an east-southeast- and south-oriented drainage route to the north of the Wichita Mountains before turning in an east-southeast direction to flow to Pauls Valley (Oklahoma) where it turns in a south direction to cut across the northeast-to-southeast oriented Arbuckle Mountains to join the Red River. The Canadian-Washita River drainage divide to the north of Pauls Valley suggests headward erosion of the east-oriented Canadian River valley captured south-oriented streams of water flowing toward the Pauls Valley area. East of the Washita River turn (at Pauls Valley) and south of Ada (Oklahoma) a large escarpment-surrounded basin opens in an east direction and suggests headward erosion of the south-oriented Washita River valley (from the Red River valley) captured large east oriented floods so as to leave a giant abandoned headcut. If so, the east-oriented flood flow at one time had been headed toward the Arkansas River valley to the north of the Ouachita Mountains in eastern Oklahoma and in Arkansas. The large east-facing 
abandoned headcut suggests the east-oriented flood flow had first been captured by headward erosion of the south-southeast oriented Clear Boggy Creek drainage basin (draining to the Red River) and then again by the south-oriented Washita River (which cuts across the Arbuckle Mountains). If correctly interpreted the new paradigm's deep "hole" rim southern margin may follow the Wichita, Arbuckle, and Ouachita Mountain crestlines, but south-oriented Red River tributary valleys captured some east-oriented floodwaters moving to the north of that margin.

This paper's figure 1 does not show the North Canadian River (which in Oklahoma joins the Canadian River) which has multiple east-oriented headwaters one of which is seen in figure 2 and which has an east-oriented drainage basin located between the east-oriented Cimarron and Canadian Rivers. From eastern New Mexico across the Texas Panhandle and most of Oklahoma the Cimarron, North Canadian, and Canadian Rivers flow roughly parallel to each other and to the more northerly Arkansas River (which the Cimarron and Canadian Rivers eventually join) and have a number of roughly parallel east-oriented tributaries as well. In addition, in the eastern Texas Panhandle and western Oklahoma the Washita River (upstream from Pauls Valley) roughly parallels the more northerly and much longer east-oriented Arkansas River tributaries while to the south of the Caprock Escarpment and of the Wichita and Arbuckle Mountains the Red River drainage basin has the same east orientation before turning in a southeast direction to eventually reach the Mississippi River delta region. In places some of these long east-oriented rivers are remarkably close to each other and asymmetric drainage divides separate them, which based on a preliminary scan of map evidence suggest the valleys eroded headward with Canadian River valley headward erosion capturing south-oriented flow to the Washita River and North Canadian River valley headward erosion capturing south-oriented flow to the Canadian River, etc., although in localized areas the flood flow appears to have been moving in east and even north directions meaning Oklahoma's drainage history needs considerable further study.

Scanning topographic maps of regions located to the south of the Purgatoire-Canadian River drainage divide region (seen in figure 2) shows the east-oriented Dry Cimarron River (which becomes the east-oriented Cimarron River) has short north- and northeast-oriented tributaries, some of which have eroded short north-oriented canyons. To the south of the east-oriented Dry Cimarron River valley are east-oriented Beaver River headwaters which appear to have beheaded southeast-oriented Canadian River tributaries (further to the east the Beaver River becomes the North Canadian River which eventually joins the Canadian River before their combined flow joins the Arkansas River). The Dry Cimarron/Cimarron River roughly parallels the Beaver/North Canadian River, but directly flows to the Arkansas River near Tulsa, Oklahoma (and upstream from where the Canadian River joins the Arkansas River). While previous investigators using the accepted paradigm perspective have often interpreted these east-oriented drainage routes to have once originated in the Sangre de Cristo Mountains and to have been beheaded by headward erosion of the south-oriented Canadian River headwaters valley the new paradigm sees deep "hole" rim uplift causing a progressive sequence of east-oriented valleys to erode headward in a west direction across immense south-oriented melt water floods from what is today in Arkansas the east-oriented Arkansas River valley located between the Ozark Mountains (north of the Arkansas River valley) and the Ouachita Mountains (south of the Arkansas River valley).

\section{Conclusions}

Contrary to previously published reports which claim headward erosion of the south-oriented Pecos River valley and south-oriented Canadian River headwaters valley captured east-oriented drainage topographic map evidence shows headward erosion of east-oriented Canadian River headwaters and tributary valleys captured multiple south-oriented streams of water which had been flowing to the Pecos River. Headward erosion of the east-oriented Canadian/Conchas River valley first captured south-oriented water responsible for erosion of the south-oriented Canadian River Canyon and subsequently captured south-oriented water responsible for the south-oriented Conchas Canyon. Headward erosion of the east-oriented Mora River valley from the south-oriented Canadian River headwaters valley ended south-oriented flow to Conchas Canyon with headward erosion of the east-oriented Sapello River valley (from the Mora River valley) ending south-oriented flow to the south-oriented Gallinas and Pecos Rivers. While western Raton Mesas areas along the Purgatoire-Canadian River drainage divide form a prominent topographic barrier that barrier fades out in an eastern direction and is located entirely within the Arkansas River drainage basin. And while in San Miguel County the Canadian-Pecos River (Arkansas River-Gulf of Mexico) drainage divide does not form a prominent topographic barrier, further to the east the Arkansas River-Gulf of Mexico drainage divide is associated with identifiable topographic barriers. For this reason, the San Miguel County (NM) Canadian-Pecos River (Arkansas River-Gulf of Mexico) drainage divide must be located along or near the new paradigm's deep "hole" rim southern margin, although it is possible the deep "hole" rim includes much of the Arkansas River drainage basin in northeast New Mexico, eastern 
Colorado, Kansas, Oklahoma, and the Texas Panhandle. Additional topographic map interpretation is needed to further document the Texas, Oklahoma, and Arkansas deep "hole" rim location and history.

\section{Acknowledgements}

Preliminary work leading to new paradigm development was done while employed as a Minot State University faculty member where other faculty members, students, and library staff greatly assisted with access to needed hard copy topographic maps.

\section{References}

Clausen, E. (2020). Use of topographic map evidence from drainage divides surrounding Wyoming's Great Divide Basin to compare two fundamentally different regional geomorphology paradigms. Earth Science Research, 9, 45-57. https://doi.org/10.5539/esr.v9n1p45

Clausen, E. (2020). Analyzing anomalous topographic map drainage system and landform evidence as a glacial history paradigm problem: a literature review. Open Journal of Geology, 10, 1072-1090. https://doi.org/10.4236/ojg.2020.1011052

Clausen, E. (2021b). How a new paradigm explains topographic map drainage system and erosional landform evidence in the Fremont County Royal Gorge area, Colorado, USA. Journal of Geography and Geology, 13(2), 32-56. https://doi.org/10.5539/jgg.v13n2p32

Dolliver, P. N. (1984). Cenozoic evolution of the Canadian River basin. Baylor Geological Studies Bulletin 42, $96 \mathrm{p}$.

Dolliver, P. N. (1985). The Plio-Pleistocene Canadian breaks of New Mexico-a profile. In Lucas, S. G. and Zidek, J., eds, Santa Rosa, Tucumcari Region. New Mexico Geological Society $36^{\text {th }}$ Annual Fall Field Conference Guidebook, 315-318.

Fenneman, N. M. (1931). Physiography of the western United States. McGraw-Hill Book Company, Inc., New York, $534 \mathrm{p}$.

Gustavson, T. C. (1986). Geomorphic development of the Canadian River valley, Texas Panhandle: an example of regional salt dissolution and subsidence. Geological Society of America Bulletin, 97, 459-472. https://doi.org/10.1130/0016-7606(1986)97<459:GDOTCR>2.0.CO;2

King, P. B. (1948). Geology of the southern Guadalupe Mountains, Texas. United States Geologic Survey Professional Paper 215, 183 p. https://doi.org/10.3133/pp215

Kuhn, T. S. (1970). The Structure of Scientific Revolutions: second edition, enlarged. University of Chicago Press, Chicago. $210 \mathrm{p}$.

Lee, W. T. (1921). The Raton Mesas of New Mexico and Colorado. Geographical Review, 11(3), 384-397. https://doi.org/10.2307/207551

Magnami, M. B., Miller, K. C., Levander, A., \& Karlstrom, K. (2004). The Yavapai-Mazatzal boundary: a long-lived tectonic element in the lithosphere of southwestern North America. Geological Society of America Bulletin, 116(7/8), 1137-1142. https://doi.org/10.1130/B25414.1

Nereson, A., Stroud, J., Karlstrom, K., Heizler, M., \& McIntosh, W. (2013). Dynamic topography of the western Great Plains: Geomorphic and ${ }^{40} \mathrm{Ar} /{ }^{39} \mathrm{Ar}$ evidence for mantle-driven uplift associated with the Jemez lineament of NE New Mexico and SE Colorado. Geosphere, 9(3), 521-545. https://doi.org/10.1130/GES00837.1

Pazzaglia, F. J. \& Kelley, S. A. (1998). Large-scale geomorphology and fission-track thermochronology in topographic and exhumation reconstructions of the southern Rocky Mountains. Rocky Mountain Geology, 33(2), 229-257. https://doi.org/10.2113/33.2.229

Pearl, R. H. (1971). Pliocene drainage of east-central Colorado and northwestern Kansas. The Mountain Geologist, 8(1), 25-30.

Plummer, F. B. (1932). Cenozoic systems in Texas. In Sellards, E. H., Atkins, W. S. \& Plummer, F. B. eds., The geology of Texas, volume 1, Stratigraphy. University of Texas Bulletin 3232, 519-818.

Spiegel, Z. (1972). Cenozoic geology of the Canadian River valley, New Mexico. In New Mexico Geological Society Guidebook 23, 118-119.

Thornbury, W. D. (1965). Regional Geomorphology of the United States. John Wiley \& Sons, New York, 609 p. https://doi.org/10.1097/00010694-196508000-00018 
Wisniewski, P. A. \& Pazzaglia, F. J. (2002). Epeirogenic controls on Canadian River incision and landscape evolution, Great Plains of northeastern New Mexico. The Journal of Geology, 110, 437-456. https://doi.org/10.1086/340441

\section{Copyrights}

Copyright for this article is retained by the author(s), with first publication rights granted to the journal.

This is an open-access article distributed under the terms and conditions of the Creative Commons Attribution license (http://creativecommons.org/licenses/by/4.0/). 